\title{
Irregular working times and metabolic disorders among truck drivers: a review
}

\author{
Elaine C Marqueze ${ }^{\mathrm{a},}$, , Melissa A Ulhôa ${ }^{\mathrm{a}}$, Claudia R C Moreno ${ }^{\mathrm{a}}$ \\ ${ }^{a}$ Environmental Health Department, School of Public Health, University of São Paulo, Dr.Arnaldo Av, 715 Zip \\ Code 01246-904, São Paulo, Brazil.
}

\begin{abstract}
A number of studies to better understand the complex physiological mechanism involved in regulating body weight have been conducted. More specifically, the hormones related to appetite, leptin and ghrelin, and their association to obesity have been a focus of investigation. Circadian patterns of these hormones are a new target of research. The behaviour of these hormones in individuals subject to atypical working times such as shiftwork remains unclear. Shiftwork is characterized by changes in biological rhythms and cumulative circadian phase changes, being associated with high rates of obesity and metabolic syndrome. Truck drivers, who work irregular shifts, frequently present a high prevalence of obesity, which might be associated with work-related factors and/or lifestyle. In this context, the aim of this paper was to discuss the relationship of body mass index, appetite-related hormones and sleep characteristics in truck drivers who work irregular shifts compared with day workers.
\end{abstract}

Keywords: Obesity, leptin, ghrelin, circadian rhythm, truck drivers.

\section{Introduction}

Driven by the current obesity epidemic, a number of studies to better understand the complex physiological mechanism involved in the regulation of body weight have been conducted. During the last two decades, appetite-related hormones, especially leptin and ghrelin, have been extensively studied in a bid to describe the pathophysiology of obesity. Both ghrelin and leptin act on the hypothalamus, controlling energy balance by increasing and decreasing food intake, respectively $[44,119]$. Thus, these hormones are considered essential elements in energy metabolism, but their mechanism of action remains unclear $[68,89]$.

Energy metabolism becomes more complicated when circadian misalignment occurs. Notably, many biological processes are regulated by the circadian clock while shiftwork is usually associated with chronic desynchronization between internal and external timing [108]. Folkard [33] posited that few workers have fixed-night complete circadian adjust- ment $(<3 \%)$, which reveals that the vast majority suffer from circadian misalignment.

In addition, shift work is associated to a high prevalence of a number of diseases including obesity as well as metabolic and sleep disorders [16]. In this context, truck drivers are subject to working irregular shifts to deliver goods on time and consequently are exposed to high risk for these diseases.

Thus, the aim of the present study was to shed light on this discussion. First, the paper covers the appetite-related hormones and obesity. Subsequently, topics on shiftwork and metabolic disorders in connection to truck drivers are addressed.

\section{Leptin}

Leptin is an anorectic peptide hormone comprising 167 amino acids, discovered in 1994 by Zhang et al [122]. The name is derived from the Greek word Leptos, which means Thin $[4,5]$.

Leptin is synthesized primarily in adipose tissue [62], and is proportionately higher in subcutaneous

\footnotetext{
*Corresponding author: Phone + 5511 3061-7905. E-mail: ecmarqueze@usp.br
} 
tissue compared to visceral tissue $[13,65]$. Leptin is also synthesized in the placenta, gastrointestinal tract and mammary glands, as well as heart and bone cartilage $[45,82,88,99]$.

Its main function is metabolic homeostasis, signalling nutritional status to the central nervous system and also to peripheral organs $[1,37,38,56,61]$.

The secretion of leptin is pulsatile and circadian; with an average of 32 pulses per day with each pulse lasting about 30 minutes $[3,25,37,40,56,67,68,88,72$, 94,96].

The leptin peak occurs at night and the nadir during the day [25]; regarding daily meals, leptin peaks post-prandially [58]. Larsson et al [62] stated that the concentration of leptin is more related to quantity of food intake than to diet content.

The serum concentration of leptin is partially related to the amount of adipose tissue [34,64], since its levels differ in individuals with the same body mass index [54]. There is also an effect of sex on its concentration. The same amount of body fat in women secretes up to twice the amount of leptin compared to men $[36,65]$.

Several parameters can change leptin concentration. In the event of circadian misalignment, a decrease in leptin levels can be observed [26,94]. By contrast, high levels of triglycerides, insulin and cortisol increase its concentration $[21,49,60,76]$.

At the time of its discovery, it was also postulated that leptin deficiency could lead to obesity. However, it was later observed that most obese individuals have high leptin levels [28,40,66,74,105]. Estimates show that the concentration of leptin in obese individuals is about five-fold that of normal-weight subjects. Less than $5 \%$ of obese individuals have low leptin concentrations [14].

A high concentration of leptin is a condition known as hyperleptinemia, and is due to changes in leptin receptors $[5,9,14,61]$ and/or deficiency in leptin transport in cerebrospinal fluid $[9,14,61]$. Hyperleptinemia is rarely due to genetic mutations $[9,11,104]$.

Somoza et al [100] showed that obesity caused by diet induces hyperleptinemia since signalling of the leptin's receptor is impaired in the hypothalamus.

Weight loss may cause a decrease in leptin levels, suggesting that the individual is experiencing a drop in energy reserves. By contrast, weight gain may increase leptin levels, albeit not as significantly. In other words, gains in metabolic reserve might not necessarily result in an abrupt increase on leptin levels $[12,46,71]$.
Regarding the effect of exercise on leptin levels, there is no consensus in the literature, since some studies have found no changes in levels $[84,106,116$, $121,123]$ whereas others report a reduction $[53,81$, $83,90,110]$. A few studies have described increased levels of circulating leptin [21,60]. Morris et al [76] showed increased leptin in a laboratory study with simulated night work proceeded by exercise.

Langenberg et al [61] pointed out that populationbased studies are needed to better understand the association between leptin and weight changes.

\section{Ghrelin}

Ghrelin was discovered later than leptin, in 1999, by Kojima et al [57] and is an orexigenic peptide hormone comprising 28 amino acids [80,105,113]. The term ghrelin is based on the word Ghre in the Proto-Indo-European language, meaning Grow, plus the suffix Relin as in the Release [120,74].

The main organ synthesizing ghrelin is the stomach $[41,78,95,113,120]$. Smaller amounts of ghrelin are produced in the intestine, pancreas, kidneys, immune system, placenta, testicles, lung, pituitary and hypothalamus [57].

The most important function of ghrelin is the stimulation of appetite, being an endogenous regulator of energy homeostasis $[39,56,78,113,120]$. According to van der Lely et al [113], ghrelin also influences behaviour, control of gastric motility and acid secretion. Ghrelin participates in the modulation of pancreatic exocrine and endocrine function. It also has an effect on glucose metabolism, cardiac performance and vascular resistance, stimulation of the secretion of GH, PRL (prolactin), ACTH and AVP (arginine vasopressin), on modulation of the proliferation of neoplastic cells and influences the immune system [113].

Ghrelin also acts in the decline of fat oxidation [112] and in the suppression of core temperature [63]. Recently, ghrelin has been identified as a factor for promoting sleep in humans and also as a mediator in neuroendocrine and behavioural responses to stressors [115]. Thus, the stomach may play an endocrine role, not only in stimulating appetite, but also in the induction of anxiety $[2,41]$.

Akin to leptin, ghrelin also has a circadian pattern and fluctuates throughout the day, peaking preprandially and dipping post-prandially, supporting the concept of endogenous ghrelin as a regulator of energy homeostasis $[3,8,18,19,20,41,52,61,78,113]$. 
Cummings et al [18] suggested that meals can be consumed voluntarily in the absence of environmental clues (time of day) due to ghrelin rhythms.

In contrast to leptin levels, ghrelin levels are lower in obese compared to normal-weight subjects $[39,41$, $73,91,105]$. The mechanisms underlying this association remain unclear, although some authors have suggested several possible explanations. Van der Lely et al [113], for instance, pointed out a similarity between this process and hyperleptinemia. Gale et al [39] suggested that the high food intake among the obese leads to decreased ghrelin concentrations.

Ghrelin concentrations are also related to the sleep/wake cycle $[3,111]$. Some studies have shown that sleep deprivation and alterations in sleep schedules may influence ghrelin levels $[27,98]$. Spiegel et al [102] found that restricting sleep to four hours for only two nights led to increased secretion of ghrelin and decreased leptin. Gauralet et al [40] also showed the same results.

High ghrelin levels may lead to increased caloric intake and consequently to obesity. Obesity, in turn, can reduce ghrelin levels $[40,41,74,101,105]$. On the another hand, weight loss due to physical activity leads to increased ghrelin levels [35].

Morris et al [76] found increased ghrelin levels after nocturnal physical exercise during simulated night work. However, levels are suppressed after diurnal exercise [6,7]. These data indicate that the time of day is an important factor to consider in the relationship between exercise and appetite-related hormones.

Langenberg et al [61] concluded that longitudinal studies are needed to determine whether ghrelin is involved in the etiology of human obesity, since it is not yet clear if leptin and ghrelin influence long-term changes in weight and body mass index.

\section{Obesity and shiftwork}

Most of the world's population is suffering negative health repercussions as a result of industrialization and computerization. One of these problems is a sedentary lifestyle, which contributes to overweight and obesity [10].

Obesity is a multifactorial syndrome (genetic, neuroendocrine, cultural and environmental), where disorders of energy balance due to desynchronization with temporal organization may play a key biological role in its genesis [29]. Garaulet et al [40] called obesity a chronobiological disease.
There are around 1.6 billion overweight and 400 million obese individuals worldwide [52]. Brazil ranks high in the list of countries for obesity prevalence, and it has been estimated that by 2025 it will be fifth in the world rankings [92]. Within a few decades, obesity will overtake tobacco as the greatest health risk [39].

In industrialized countries, obesity and metabolic syndrome are major causes of morbidity and mortality, where industrialization is a major predisposing factor for positive energy balance [29].

Besides the well-known risk factors such as poor diet and sedentary lifestyle, shiftwork has been widely associated with weight gain [109]. In parallel, shorter sleep times and longer working hours have resulted from economic competitiveness and globalization [10].

Epidemiological studies have indicated a causal link among shorter sleep times, shiftwork and metabolic diseases [118].

Garaulet et al [40] reported a $1.5 \mathrm{~h}$ decrease in sleep duration over the last century, with subsequent weight gain. However, it is noteworthy that circadian desynchronization is triggered not only by short sleep duration, but also by change in the timing of sleep, a factor favouring the development of obesity [29].

Ostry et al [85] also showed a positive association between high work load, long working hours and body mass index. This confirms the influence of work organizational factors on the prevalence of overweight and obesity [30]. These aspects will be discussed later in the current paper.

\section{Shiftwork and metabolic disorders}

The association between shiftwork and obesity is likely explained by behavioural disruption and biological factors involved in energy balance, and desynchronization of biological rhythms [3,76,108]. It should be highlighted that shift and night workers represent about $20 \%$ of the workforce of the European community [3] and also of the United States [42]. Fischer [32] estimated that in Brazil, this percentage attains $15 \%$ of the workforce.

Since shiftwork is an independent risk factor for weight gain [17], these data demonstrate the relevance of this subject.

Aspects such as time of day, frequency and regularity of meals, and also the desynchronization of circadian rhythms, can affect energy metabolism and body weight regulation [29]. While there is a de- 
crease in hunger during the night when satiety requires the intake of smaller portions of food [69], most food consumption among shift workers occurs at night. This is harmful to energy balance [47] since postprandial thermogenesis is lower [93] and the body is not designed for energy consumption at night [3].

Both content and quantity of food consumed can be influenced by shiftwork, as well as the disruption of traditional meals at home. Some studies have shown that shiftwork has little influence on eating habits [31] whereas other authors have shown that diet content is better among shift workers than day workers [17].

De Assis et al [22] found no difference in total energy intake and nutrient composition. Thus, it appears that the amount of energy intake is not greatly affected by shiftwork [87].

In contrast, Sudo and Ohtsuka [107] found a lower caloric intake among shift workers compared to day workers, along with lower intake of protein, fat and carbohydrate. These differences were attributed to a lower frequency of meals during the day and to the low nutrient composition of night-time meals among shift workers.

Indeed, the frequency of diurnal meals is usually reduced, whereas snack consumption during night shifts, with higher energy intake, is increased [3]. Further studies investigating chronobiological aspects of feeding behaviour are warranted, since night-time feeding also affects circadian rhythms [77]. Another point to be considered is that the eating habits of shift workers are specific to the type of work, work environment and food supply. The type and frequency of meals are influenced more by time limitations than by feelings of hunger [114].

Another important aspect is physical activity since sedentary habits are associated with a high prevalence of obesity. In general, shift work decreases opportunities for doing exercise. However there is no scientific evidence that exercise can reduce body mass index among shift workers [3].

Finally, the partial sleep deprivation in shift workers, besides problems of circadian desynchronization, with short sleeping times to increase opportunities and time for eating, leads to increased food intake. There is also a change in body thermoregulation and consequent decrease in expended energy, in turn leading to increased body weight [40].

Metabolic changes include elevated levels of cholesterol, triglycerides, insulin and glucose [15,30,42, $50,51,79,118]$. Shift work may also lead to lower levels of HDL and leptin, insulin resistance, higher waist-hip circumference, higher waist circumference, higher systolic blood pressure and obesity $[3,15,23$, $24,30,42,48,50,51,55,59,70,77,79,86,94,96,118]$.

Studies have highlighted that blood glucose levels are lower in shift workers than in day workers [30]. Nevertheless, other studies failed to find differences between these groups [42,50,51].

In view of these findings, it appears that shiftwork has a strong association with metabolic disorders.

\section{Truck drivers}

Truck drivers work irregular hours due to workload demands. Long working hours, including night work, is the main characteristic of the job. Working at night may contribute to chronic sleep deprivation and obesity, which are commonly observed among these professionals [75].

Generally, truck drivers have a high prevalence of sedentary lifestyle, poor eating habits and obesity. Most are smokers and have high blood pressure $[43,75]$. These characteristics put this population at risk for a number of diseases such as cardiovascular, gastrointestinal and metabolic diseases. However, few studies have investigated the health status of professional drivers.

Regarding public transport drivers, Siedlecki [97] stated that several studies show that these professionals have a high risk for cardiovascular disease. Obesity, sedentary lifestyle and smoking number among the main risk factors for cardiovascular disease.

Stoohs et al [103] showed a $16 \%$ prevalence of hypertension among truck drivers. It is important to note the high percentage of these individuals who were unaware they had the disease $(75 \%)$.

In a cross-sectional survey involving 92 truck drivers, Whitfield-Jacobson et al [117] found that $85.9 \%$ of drivers were overweight and $56.5 \%$ were obese. By contrast, Moreno et al [75] found a lower prevalence $(28.3 \%)$ of obese in a study of 4,878 drivers. In fact, both studies showed a high percentage, indicating that this job is associated with obesity.

The irregular working hours is one possible explanation for the high number of obese among these workers. Irregular working times contribute to unhealthy dietary habits [87], as well as fewer opportunities for regular physical activity.

Whitfield-Jacobson et al [117] suggested that the implementation of wellness programs for drivers could prevent several diseases, such as obesity. These programs could include educational activities and 
support as well as provide nutritional guidance to truck-stop restaurants. The development of such prevention programs is justified not only for economic reasons, but mainly for the safety of drivers who travel the highways [97].

In summary, the category of truck drivers seems to have a high prevalence of obesity, which could be associated with factors such as shiftwork, lifestyle and diet habits. We emphasize the need for studies with greater control of variables to investigate the relationships among obesity, sleep and work organization.

\section{Final remarks}

The explanation for the negative effects of shiftwork on health is both complicated and complex. Moreover, its impact on metabolic risk factors is not yet completely understood. However, many studies indicate that shiftwork has a substantial negative influence on physiological functions, mediated by circadian misalignment.

As outlined above, epidemiological evidence shows that shiftwork, specifically the work schedule of truck drivers, is associated with increased rates of obesity and metabolic disorders. This association has been explained by inadequate work organization, which changes sleeping and eating times. Consequently, the majority of truck drivers suffer from circadian misalignment. There is an imbalance between energy consumption and energy expenditure in shift workers, probably due to the desynchronization of appetite-related hormones. In addition, constant changes in meal times can also affect this internal mechanism.

Despite the high prevalence of obesity among shift workers, its underlying mechanisms remain unclear. In general, factors such as unhealthy lifestyle, high frequency of snacks, and short sleep times, may contribute to circadian desynchronization.

Specifically for truck drivers, irregular working times seem to be a decisive factor in the prevalence of obesity.

We emphasize that irregular working times not only reduce sleep duration, but also lead to a number of changes in truck drivers' lives. Understanding the effects of these changes could provide key insights to the pathophysiology of obesity in this population.

Support: CNPq-474199/2008-8 and CNPq-200388/2010-0.

\section{References}

[1] Ahima RS, Flier JS. Leptin. Annu Rev Physiol. 2000;62:41337.

[2] Asakawa A, Inui A, Kaga T, Yuzuriha H, Nagata T, Fujimiya $\mathrm{M}$, et al. A role of ghrelin in neuroendocrine and behavioral responses to stress in mice. Neuroendocrinology. 2001 Sep;74(3):143-7.

[3] Atkinson G, Fullick S, Grindey C, Maclaren D. Exercise, energy balance and the shift worker. Sports Med. 2008;38(8):671-85.

[4] Auwerx J, Staels B. Leptin. Lancet. 1998 Mar 7;351(9104):737-42.

[5] Bray GA. Progress in understanding the genetics of obesity. J Nutr. 1997 May;127(5 Suppl):940S-2S.

[6] Broom DR, Batterham RL, King JA, Stensel DJ. Influence of resistance and aerobic exercise on hunger, circulating levels of acylated ghrelin, and peptide YY in healthy males. Am J Physiol Regul Integr Comp Physiol. 2009 Jan;296(1):R29-35.

[7] Broom DR, Stensel DJ, Bishop NC, Burns SF, Miyashita M. Exercise-induced suppression of acylated ghrelin in humans. J Appl Physiol. 2007 Jun;102(6):2165-71.

[8] Callahan HS, Cummings DE, Pepe MS, Breen PA, Matthys CC, Weigle DS. Postprandial suppression of plasma ghrelin level is proportional to ingested caloric load but does not predict intermeal interval in humans. J Clin Endocrinol Metab. 2004 Mar;89(3):1319-24.

[9] Caro JF, Kolaczynski JW, Nyce MR, Ohannesian JP, Opentanova I, Goldman WH, et al. Decreased cerebrospinalfluid/serum leptin ratio in obesity: a possible mechanism for leptin resistance. Lancet. 1996 Jul 20;348(9021):159-61.

[10]Chaput JP, Tremblay A. Obesity and physical inactivity: the relevance of reconsidering the notion of sedentariness. Obes Facts. 2009;2(4):249-54.

[11]Clement K, Vaisse C, Lahlou N, Cabrol S, Pelloux V, Cassuto $\mathrm{D}$, et al. A mutation in the human leptin receptor gene causes obesity and pituitary dysfunction. Nature. 1998 Mar 26;392(6674):398-401.

[12] Considine RV, Caro JF. Leptin and the regulation of body weight. Int J Biochem Cell Biol. 1997 Nov;29(11):1255-72.

[13] Considine RV, Cooksey RC, Williams LB, Fawcett RL, Zhang P, Ambrosius WT, et al. Hexosamines regulate leptin production in human subcutaneous adipocytes. J Clin Endocrinol Metab. 2000 Oct;85(10):3551-6.

[14] Considine RV, Sinha MK, Heiman ML, Kriauciunas A, Stephens TW, Nyce MR, et al. Serum immunoreactive-leptin concentrations in normal-weight and obese humans. N Engl J Med. 1996 Feb 1;334(5):292-5.

[15]Copertaro A, Bracci M, Barbaresi M, Santarelli L. [Role of waist circumference in the diagnosis of metabolic syndrome and assessment of cardiovascular risk in shift workers]. Med Lav. 2008 Nov-Dec;99(6):444-53.

[16] Costa G. Shift work and occupational medicine: an overview. Occup Med (Lond). 2003 Mar;53(2):83-8.

[17]Croce N, Bracci M, Ceccarelli G, Barbadoro P, Prospero E, Santarellia L. [Body mass index in shift workers: relation to diet and physical activity]. G Ital Med Lav Ergon. 2007 JulSep;29(3 Suppl):488-9.

[18]Cummings DE, Overduin J, Foster-Schubert KE. Gastric bypass for obesity: mechanisms of weight loss and diabetes resolution. J Clin Endocrinol Metab. 2004 Jun;89(6):2608-15.

[19] Cummings DE, Purnell JQ, Frayo RS, Schmidova K, Wisse $\mathrm{BE}$, Weigle DS. A preprandial rise in plasma ghrelin levels suggests a role in meal initiation in humans. Diabetes. 2001 Aug;50(8):1714-9. 
[20]Cummings DE, Weigle DS, Frayo RS, Breen PA, Ma MK, Dellinger EP, et al. Plasma ghrelin levels after diet-induced weight loss or gastric bypass surgery. N Engl J Med. 2002 May 23;346(21):1623-30.

[21]Dagogo-Jack S, Tykodi G, Umamaheswaran I. Inhibition of cortisol biosynthesis decreases circulating leptin levels in obese humans. J Clin Endocrinol Metab. 2005 Sep;90(9):5333-5.

[22] de Assis MA, Kupek E, Nahas MV, Bellisle F. Food intake and circadian rhythms in shift workers with a high workload. Appetite. 2003 Apr;40(2):175-83.

[23] Di Lorenzo L, De Pergola G, Zocchetti C, L'Abbate N, Basso A, Pannacciulli N, et al. Effect of shift work on body mass index: results of a study performed in 319 glucose-tolerant men working in a Southern Italian industry. Int J Obes Relat Metab Disord. 2003 Nov;27(11):1353-8.

[24]Di Milia L, Mummery K. The association between job related factors, short sleep and obesity. Ind Health. 2009 Aug;47(4):363-8.

[25] Downs JL, Urbanski HF. Aging-related sex-dependent loss of the circulating leptin 24-h rhythm in the rhesus monkey. J Endocrinol. 2006 Jul;190(1):117-27.

[26] Duez H, Staels B. Rev-erb-alpha: an integrator of circadian rhythms and metabolism. J Appl Physiol. 2009 Dec;107(6):1972-80.

[27]Dzaja A, Dalal MA, Himmerich H, Uhr M, Pollmacher T, Schuld A. Sleep enhances nocturnal plasma ghrelin levels in healthy subjects. Am J Physiol Endocrinol Metab. 2004 Jun;286(6):E963-7.

[28]Eden Engstrom B, Burman P, Holdstock C, Karlsson FA. Effects of growth hormone $(\mathrm{GH})$ on ghrelin, leptin, and adiponectin in $\mathrm{GH}$-deficient patients. J Clin Endocrinol Metab. 2003 Nov;88(11):5193-8

[29]Ekmekcioglu C, Touitou Y. Chronobiological aspects of food intake and metabolism and their relevance on energy balance and weight regulation. Obes Rev. 2010 Jan 27.

[30] Esquirol Y, Bongard V, Mabile L, Jonnier B, Soulat JM, Perret B. Shift work and metabolic syndrome: respective impacts of job strain, physical activity, and dietary rhythms. Chronobiol Int. 2009 Apr;26(3):544-59.

[31] Fernandez Rodriguez MJ, Bautista Castano I, Bello Lujan L, Hernandez Bethencourt L, Sanchez Villegas A, Serra Majem L. [Nutritional evaluation of health shift workers from the Canary Islands]. Nutr Hosp. 2004 Sep-Oct;19(5):286-91.

[32] Fischer FM. Fatores individuais e condições de trabalho e de vida na tolerância ao trabalho em turnos, in: Fischer FM, Moreno CRC, Rotenberg L (org). Trabalho em turnos e noturno na sociedade 24 horas. Atheneu: São Paulo, 2004, pp 65-76.

[33] Folkard S. Do permanent night workers show circadian adjustment? A review based on the endogenous melatonin rhythm. Chronobiol Int. 2008 Apr;25(2):215-24.

[34]Fors H, Matsuoka H, Bosaeus I, Rosberg S, Wikland KA, Bjarnason R. Serum leptin levels correlate with growth hormone secretion and body fat in children. J Clin Endocrinol Metab. 1999 Oct;84(10):3586-90.

[35]Foster-Schubert KE, McTiernan A, Frayo RS, Schwartz RS, Rajan KB, Yasui Y, et al. Human plasma ghrelin levels increase during a one-year exercise program. J Clin Endocrinol Metab. 2005 Feb;90(2):820-5

[36] Frederich RC, Hamann A, Anderson S, Lollmann B, Lowell BB, Flier JS. Leptin levels reflect body lipid content in mice: evidence for diet-induced resistance to leptin action. Nat Med. 1995 Dec;1(12):1311-4
[37] Friedman JM. The function of leptin in nutrition, weight, and physiology. Nutr Rev. 2002 Oct;60(10 Pt 2):S1-14; discussion S68-84, 5-7.

[38] Fruhbeck G, Gomez-Ambrosi J, Muruzabal FJ, Burrell MA The adipocyte: a model for integration of endocrine and metabolic signaling in energy metabolism regulation. Am J Physiol Endocrinol Metab. 2001 Jun;280(6):E827-47.

[39] Gale SM, Castracane VD, Mantzoros CS. Energy homeostasis, obesity and eating disorders: recent advances in endocrinology. J Nutr. 2004 Feb;134(2):295-8.

[40] Garaulet M, Ordovas JM, Madrid JA. The chronobiology, etiology and pathophysiology of obesity. Int $\mathrm{J}$ Obes (Lond). 2010 Dec;34(12):1667-83.

[41] Ghigo E, Broglio F, Arvat E, Maccario M, Papotti M, Muccioli G. Ghrelin: more than a natural GH secretagogue and/or an orexigenic factor. Clin Endocrinol (Oxf). 2005 Jan;62(1):117.

[42] Ha M, Park J. Shiftwork and metabolic risk factors of cardiovascular disease. J Occup Health. 2005 Mar;47(2):89-95.

[43] Hakkanen H, Summala H. Sleepiness at work among commercial truck drivers. Sleep. 2000 Feb 1;23(1):49-57.

[44]Halaas JL, Gajiwala KS, Maffei M, Cohen SL, Chait BT, Rabinowitz D, et al. Weight-reducing effects of the plasma protein encoded by the obese gene. Science. $1995 \mathrm{Ju}$ 28;269(5223):543-6.

[45] Hassink SG, de Lancey E, Sheslow DV, Smith-Kirwin SM, O'Connor DM, Considine RV, et al. Placental leptin: an important new growth factor in intrauterine and neonatal development? Pediatrics. 1997 Jul;100(1):E1.

[46] Hebebrand J, Blum WF, Barth N, Coners H, Englaro P, Juul A, et al. Leptin levels in patients with anorexia nervosa are reduced in the acute stage and elevated upon short-term weight restoration. Mol Psychiatry. 1997 Jul;2(4):330-4.

[47] Holmback U, Forslund A, Lowden A, Forslund J, Akerstedt T, Lennernas M, et al. Endocrine responses to nocturnal eating-possible implications for night work. Eur J Nutr. 2003 Apr;42(2):75-83.

[48] Ishizaki M, Morikawa Y, Nakagawa H, Honda R, Kawakami $\mathrm{N}$, Haratani $\mathrm{T}$, et al. The influence of work characteristics on body mass index and waist to hip ratio in Japanese employees. Ind Health. 2004 Jan;42(1):41-9.

[49] Kanaley JA, Weltman JY, Pieper KS, Weltman A, Hartman ML. Cortisol and growth hormone responses to exercise at different times of day. J Clin Endocrinol Metab. 2001 Jun;86(6):2881-9.

[50] Karlsson B, Knutsson A, Lindahl B. Is there an association between shift work and having a metabolic syndrome? Results from a population based study of 27,485 people. Occup Environ Med. 2001 Nov;58(11):747-52.

[51] Karlsson BH, Knutsson AK, Lindahl BO, Alfredsson LS Metabolic disturbances in male workers with rotating threeshift work. Results of the WOLF study. Int Arch Occup Environ Health. 2003 Jul;76(6):424-30.

[52] Karra E, Batterham RL. The role of gut hormones in the regulation of body weight and energy homeostasis. Mol Cell Endocrinol. 2010 Mar 25;316(2):120-8.

[53] Keller P, Keller C, Steensberg A, Robinson LE, Pedersen BK. Leptin gene expression and systemic levels in healthy men: effect of exercise, carbohydrate, interleukin-6, and epinephrine. J Appl Physiol. 2005 May;98(5):1805-12.

[54] Kennedy A, Gettys TW, Watson P, Wallace P, Ganaway E, Pan $\mathrm{Q}$, et al. The metabolic significance of leptin in humans: gender-based differences in relationship to adiposity, insulin sensitivity, and energy expenditure. J Clin Endocrinol Metab. 1997 Apr;82(4):1293-300. 
[55] Ketchum ES, Morton JM. Disappointing weight loss among shift workers after laparoscopic gastric bypass surgery. Obes Surg. 2007 May; 17(5):581-4.

[56]Klok MD, Jakobsdottir S, Drent ML. The role of leptin and ghrelin in the regulation of food intake and body weight in humans: a review. Obes Rev. 2007 Jan;8(1):21-34.

[57] Kojima M, Hosoda H, Date Y, Nakazato M, Matsuo H, Kangawa K. Ghrelin is a growth-hormone-releasing acylated peptide from stomach. Nature. 1999 Dec 9;402(6762):656-60.

[58]Kolaczynski JW, Considine RV, Ohannesian J, Marco C, Opentanova I, Nyce MR, et al. Responses of leptin to shortterm fasting and refeeding in humans: a link with ketogenesis but not ketones themselves. Diabetes. 1996 Nov;45(11):15115.

[59] Kubo T, Oyama I, Nakamura T, Shirane K, Otsuka H, Kunimoto M, et al. Retrospective cohort study of the risk of obesity among shift workers: findings from the Industry-based Shift Workers' Health study, Japan. Occup Environ Med. 2011 May;68(5):327-31.

[60] Laferrere B, Abraham C, Awad M, Jean-Baptiste S, Hart AB Garcia-Lorda $\mathrm{P}$, et al. Inhibiting endogenous cortisol blunts the meal-entrained rise in serum leptin. J Clin Endocrinol Metab. 2006 Jun;91(6):2232-8

[61] Langenberg C, Bergstrom J, Laughlin GA, Barrett-Connor E. Ghrelin, adiponectin, and leptin do not predict long-term changes in weight and body mass index in older adults: longitudinal analysis of the Rancho Bernardo cohort. Am J Epidemiol. 2005 Dec 15;162(12):1189-97.

[62] Larsson H, Elmstahl S, Berglund G, Ahren B. Evidence for leptin regulation of food intake in humans. J Clin Endocrinol Metab. 1998 Dec;83(12):4382-5.

[63] Lawrence CB, Snape AC, Baudoin FM, Luckman SM. Acute central ghrelin and $\mathrm{GH}$ secretagogues induce feeding and activate brain appetite centers. Endocrinology. 2002 Jan;143(1):155-62.

[64]Lee JH, Reed DR, Price RA. Leptin resistance is associated with extreme obesity and aggregates in families. Int $\mathrm{J}$ Obes Relat Metab Disord. 2001 Oct;25(10):1471-3.

[65]Leibel RL. The role of leptin in the control of body weight. Nutr Rev. 2002 Oct;60(10 Pt 2):S15-9; discussion S68-84, 5-7.

[66] Leidy HJ, Gardner JK, Frye BR, Snook ML, Schuchert MK, Richard EL, et al. Circulating ghrelin is sensitive to changes in body weight during a diet and exercise program in normalweight young women. J Clin Endocrinol Metab. 2004 Jun;89(6):2659-64.

[67]Licinio J, Mantzoros C, Negrao AB, Cizza G, Wong ML, Bongiorno PB, et al. Human leptin levels are pulsatile and inversely related to pituitary-adrenal function. Nat Med. 1997 May;3(5):575-9.

[68]Licinio J, Negrao AB, Mantzoros C, Kaklamani V, Wong ML, Bongiorno PB, et al. Synchronicity of frequently sampled, 24$\mathrm{h}$ concentrations of circulating leptin, luteinizing hormone, and estradiol in healthy women. Proc Natl Acad Sci U S A. 1998 Mar 3;95(5):2541-6.

[69]Lowden A, Holmback U, Akerstedt T, Forslund A, Forslund J, Lennernas M. Time of day type of food--relation to mood and hunger during 24 hours of constant conditions. J Hum Ergol (Tokyo). 2001 Dec;30(1-2):381-6.

[70]Lowden A, Moreno C, Holmback U, Lennernas M, Tucker P. Eating and shift work - effects on habits, metabolism and performance. Scand J Work Environ Health. 2010 Mar;36(2):150-62.

[71] Mantzoros C, Flier JS, Lesem MD, Brewerton TD, Jimerson DC. Cerebrospinal fluid leptin in anorexia nervosa: correlation with nutritional status and potential role in resistance to weight gain. J Clin Endocrinol Metab. 1997 Jun;82(6):184551.

[72] Mantzoros CS. The role of leptin in human obesity and disease: a review of current evidence. Ann Intern Med. 1999 Apr 20;130(8):671-80.

[73] McLaughlin T, Abbasi F, Lamendola C, Frayo RS, Cummings DE. Plasma ghrelin concentrations are decreased in insulinresistant obese adults relative to equally obese insulinsensitive controls. J Clin Endocrinol Metab. 2004 Apr;89(4):1630-5.

[74] Monti V, Carlson JJ, Hunt SC, Adams TD. Relationship of ghrelin and leptin hormones with body mass index and waist circumference in a random sample of adults. J Am Diet Assoc. 2006 Jun;106(6):822-8; quiz 9-30.

[75] Moreno CR, Louzada FM, Teixeira LR, Borges F, LorenziFilho G. Short sleep is associated with obesity among truck drivers. Chronobiol Int. 2006;23(6):1295-303.

[76] Morris CJ, Fullick S, Gregson W, Clarke N, Doran D, MacLaren D, et al. Paradoxical post-exercise responses of acylated ghrelin and leptin during a simulated night shift. Chronobiol Int. 2010 May;27(3):590-605.

[77] Mosendane T, Raal FJ. Shift work and its effects on the cardiovascular system. Cardiovasc J Afr. 2008 JulAug;19(4):210-5.

[78] Mundinger TO, Cummings DE, Taborsky GJ, Jr. Direct stimulation of ghrelin secretion by sympathetic nerves. Endocrinology. 2006 Jun;147(6):2893-901.

[79] Nakamura K, Shimai S, Kikuchi S, Tominaga K, Takahashi H, Tanaka M, et al. Shift work and risk factors for coronary heart disease in Japanese blue-collar workers: serum lipids and anthropometric characteristics. Occup Med (Lond). 1997 Apr;47(3):142-6.

[80]Nakazato M, Murakami N, Date Y, Kojima M, Matsuo H, Kangawa $\mathrm{K}$, et al. A role for ghrelin in the central regulation of feeding. Nature. 2001 Jan 11;409(6817):194-8.

[81] Nindl BC, Kraemer WJ, Arciero PJ, Samatallee N, Leone CD, Mayo MF, et al. Leptin concentrations experience a delayed reduction after resistance exercise in men. Med Sci Sports Exerc. 2002 Apr;34(4):608-13.

[82] Nishi Y, Isomoto H, Uotani S, Wen CY, Shikuwa S, Ohnita K, et al. Enhanced production of leptin in gastric fundic mucosa with Helicobacter pylori infection. World $\mathrm{J}$ Gastroenterol. 2005 Feb 7;11(5):695-9.

[83] Noland RC, Baker JT, Boudreau SR, Kobe RW, Tanner CJ, Hickner RC, et al. Effect of intense training on plasma leptin in male and female swimmers. Med Sci Sports Exerc. 2001 Feb;33(2):227-31.

[84] Olive JL, Miller GD. Differential effects of maximal- and moderate-intensity runs on plasma leptin in healthy trained subjects. Nutrition. 2001 May;17(5):365-9.

[85] Ostry AS, Radi S, Louie AM, LaMontagne AD. Psychosocial and other working conditions in relation to body mass index in a representative sample of Australian workers. BMC Public Health. 2006;6:53.

[86] Parkes KR. Shift work and age as interactive predictors of body mass index among offshore workers. Scand J Work Environ Health. $2002 \mathrm{Feb}$;28(1):64-71.

[87] Pasqua IC, Moreno CR. The nutritional status and eating habits of shift workers: a chronobiological approach. Chronobiol Int. 2004;21(6):949-60.

[88] Prolo P, Wong ML, Licinio J. Leptin. Int J Biochem Cell Biol. 1998 Dec;30(12):1285-90.

[89] Ramel A, Arnarson A, Parra D, Kiely M, Bandarra NM, Martinez JA, et al. Gender difference in the prediction of weight loss by leptin among overweight adults. Ann Nutr Metab. 2010;56(3):190-7. 
[90]Reseland JE, Anderssen SA, Solvoll K, Hjermann I, Urdal P, Holme I, et al. Effect of long-term changes in diet and exercise on plasma leptin concentrations. Am J Clin Nutr. 2001 Feb;73(2):240-5.

[91] Robertson MD, Henderson RA, Vist GE, Rumsey RD. Plasma ghrelin response following a period of acute overfeeding in normal weight men. Int J Obes Relat Metab Disord. 2004 Jun;28(6):727-33

[92]Romero CEM, ZanescoA. The role of leptin and ghrelin on the genesis of obesity. Rev Nutr. 2006 Jan/Fev;19(1):85-91.

[93]Romon M, Edme JL, Boulenguez C, Lescroart JL, Frimat P. Circadian variation of diet-induced thermogenesis. Am J Clin Nutr. 1993 Apr;57(4):476-80.

[94] Scheer FA, Hilton MF, Mantzoros CS, Shea SA. Adverse metabolic and cardiovascular consequences of circadian misalignment. Proc Natl Acad Sci U S A. 2009 Mar 17;106(11):4453-8.

[95] Schwartz MW, Morton GJ. Obesity: keeping hunger at bay. Nature. 2002 Aug 8;418(6898):595-7.

[96] Shea SA, Hilton MF, Orlova C, Ayers RT, Mantzoros CS. Independent circadian and sleep/wake regulation of adipokines and glucose in humans. J Clin Endocrinol Metab. 2005 May;90(5):2537-44.

[97] Siedlecka J. [Selected work-related health problems in drivers of public transport vehicles]. Med Pr. 2006;57(1):47-52.

[98] Simon C, Gronfier C, Schlienger JL, Brandenberger G. Circadian and ultradian variations of leptin in normal man under continuous enteral nutrition: relationship to sleep and body temperature. J Clin Endocrinol Metab. 1998 Jun;83(6):1893-9.

[99] Smith-Kirwin SM, O'Connor DM, De Johnston J, Lancey ED, Hassink SG, Funanage VL. Leptin expression in human mammary epithelial cells and breast milk. J Clin Endocrinol Metab. 1998 May;83(5):1810-3.

[100] Somoza B, Guzman R, Cano V, Merino B, Ramos P, Diez-Fernandez $C$, et al. Induction of cardiac uncoupling protein-2 expression and adenosine 5'-monophosphate-activated protein kinase phosphorylation during early states of dietinduced obesity in mice. Endocrinology. 2007 Mar;148(3):924-31.

[101] Soriano-Guillen L, Barrios V, Chowen JA, Sanchez I, Vila S, Quero J, et al. Ghrelin levels from fetal life through early adulthood: relationship with endocrine and metabolic and anthropometric measures. J Pediatr. 2004 Jan;144(1):30-5.

[102] Spiegel K, Tasali E, Penev P, Van Cauter E. Brief communication: Sleep curtailment in healthy young men is associated with decreased leptin levels, elevated ghrelin levels, and increased hunger and appetite. Ann Intern Med. 2004 Dec 7;141(11):846-50.

[103] Stoohs RA, Bingham LA, Itoi A, Guilleminault C, Dement WC. Sleep and sleep-disordered breathing in commercial long-haul truck drivers. Chest. 1995 May;107(5):1275-82.

[104] Strobel A, Issad T, Camoin L, Ozata M, Strosberg AD. A leptin missense mutation associated with hypogonadism and morbid obesity. Nat Genet. 1998 Mar;18(3):213-5.

[105] Stylianou C, Galli-Tsinopoulou A, Farmakiotis D, Rousso I, Karamouzis M, Koliakos G, et al. Ghrelin and leptin levels in obese adolescents. Relationship with body fat and insulin resistance. Hormones (Athens). 2007 Oct-Dec;6(4):295303.
[106] Sudi K, Jurimae J, Payerl D, Pihl E, Moller R, Tafeit E, et al. Relationship between subcutaneous fatness and leptin in male athletes. Med Sci Sports Exerc. 2001 Aug;33(8):1324-9.

[107] Sudo N, Ohtsuka R. Nutrient intake among female shift workers in a computer factory in Japan. Int J Food Sci Nutr. $2001 \mathrm{Jul} ; 52(4): 367-78$.

[108] Szosland D. Shift work and metabolic syndrome, diabetes mellitus and ischaemic heart disease. Int J Occup Med Environ Health. 2010 Oct 8:1-5.

[109] Szpak A, Jamiolkowski J, Witana K. Overweight and obesity and their determinants among men from Podlasie region in the years 1987-1998. Rocz Akad Med Bialymst. 2005;50 Suppl 1:245-9.

[110] Tock L, Prado WL, Caranti DA, Cristofalo DM, Lederman H, Fisberg M, et al. Nonalcoholic fatty liver disease decrease in obese adolescents after multidisciplinary therapy. Eur J Gastroenterol Hepatol. 2006 Dec;18(12):1241-5.

[111] Treuer T. The potential role of ghrelin in the mechanism of sleep deprivation therapy for depression. Sleep Med Rev. 2007 Dec;11(6):523-4; author reply 4-5.

[112] Tschop M, Smiley DL, Heiman ML. Ghrelin induces adiposity in rodents. Nature. 2000 Oct 19;407(6806):908-13.

[113] van der Lely AJ, Tschop M, Heiman ML, Ghigo E. Biological, physiological, pathophysiological, and pharmacological aspects of ghrelin. Endocr Rev. 2004 Jun;25(3):426-57.

[114] Waterhouse J, Buckley P, Edwards B, Reilly T. Measurement of, and some reasons for, differences in eating habits between night and day workers. Chronobiol Int. 2003 Nov;20(6):1075-92.

[115] Weikel JC, Wichniak A, Ising M, Brunner H, Friess E, Held $\mathrm{K}$, et al. Ghrelin promotes slow-wave sleep in humans. Am J Physiol Endocrinol Metab. 2003 Feb;284(2):E407-15.

[116] Weltman A, Pritzlaff CJ, Wideman L, Considine RV, Fryburg DA, Gutgesell ME, et al. Intensity of acute exercise does not affect serum leptin concentrations in young men. Med Sci Sports Exerc. 2000 Sep;32(9):1556-61.

[117] Whitfield Jacobson PJ, Prawitz AD, Lukaszuk JM. Long-haul truck drivers want healthful meal options at truckstop restaurants. J Am Diet Assoc. 2007 Dec;107(12):2125-9.

[118] Wolk R, Somers VK. Sleep and the metabolic syndrome. Exp Physiol. 2007 Jan;92(1):67-78.

[119] Wren AM, Seal LJ, Cohen MA, Brynes AE, Frost GS, Murphy KG, et al. Ghrelin enhances appetite and increases food intake in humans. J Clin Endocrinol Metab. 2001 Dec;86(12):5992.

[120] Wu JT, Kral JG. Ghrelin: integrative neuroendocrine peptide in health and disease. Ann Surg. 2004 Apr;239(4):464-74.

[121] Zafeiridis A, Smilios I, Considine RV, Tokmakidis SP. Serum leptin responses after acute resistance exercise protocols. J Appl Physiol. 2003 Feb;94(2):591-7.

[122] Zhang Y, Proenca R, Maffei M, Barone M, Leopold L, Friedman JM. Positional cloning of the mouse obese gene and its human homologue. Nature. 1994 Dec 1;372(6505):425-32.

[123] Zoladz JA, Konturek SJ, Duda K, Majerczak J, Sliwowski Z, Grandys M, et al. Effect of moderate incremental exercise, performed in fed and fasted state on cardiorespiratory variables and leptin and ghrelin concentrations in young healthy men. J Physiol Pharmacol. 2005 Mar;56(1):6385 